\title{
Kualitas Layanan dan Loyalitas Pasien (Studi pada Rumah Sakit Umum Swasta di Kota Singaraja-Bali)
}

\author{
Ketut Gunawan \\ Fakultas Ekonomi, Universitas Panji Sakti Singaraja \\ E-mail: ketut_gunawan292@yahoo.com \\ Sundring Pantja Djati \\ Fakultas Ekonomi, Universitas Kristen Petra \\ E-mail: spdjati@petra.ac.id
}

\begin{abstract}
This study aims to determine the influence of service quality dimensions of patient loyalty in private hospitals in the town of Singaraja-Bali. The technique of data collection was conducted by giving questionnaire to patients in those hospitals. The results of this study indicate that: first, service quality which consists of tangible, reliability, responsiveness, assurance, and empathy have a significant influence on patient loyalty not only partially but also simultaneously; second, reliability is a dimension that has a dominant influence on the patient loyalty.
\end{abstract}

Keywords: service quality, patient loyalty, reliability

\section{PENDAHULUAN}

Setiap produsen berusaha merancang perbedaan yang berarti untuk membedakan produknya dengan produk yang ditawarkan pesaingnya, sehingga setiap produk memiliki ciri khas masing-masing yang membedakan dengan produk pesaingnya (Kotler, 2002).

Perbedaan produk dengan pesaingnya terlihat juga pada perusahaan jasa Rumah Sakit. Rumah Sakit sebagai suatu perusahaan yang bergerak dalam bidang jasa pelayanan kesehatan berupaya memberikan pelayanan kesehatan yang baik dan berkualitas. Pelayanan yang baik dan berkualitas dengan sendirinya akan mendatangkan kepuasan pasien dan sekaligus akan memberikan keuntungan bagi pihak Rumah Sakit.

Rumah Sakit merupakan salah satu pelayanan jasa yang dalam melakukan aktivitasnya, tidak boleh lepas dari perkembangan ilmu pengetahuan dan teknologi. Kedua hal tersebut meningkatkan kesadaran dan tuntutan masyarakat terhadap pelayanan jasa kesehatan yang semakin baik. Hal ini juga menyebabkan nilai (value) masyarakat berubah terhadap pelayanan jasa kesehatan yang lebih bermutu. Perubahan ini merupakan tantangan bagi pihak Rumah Sakit yang dihadapkan pada lingkungan usaha yang berubah.

Tingkat persaingan yang semakin ketat dikalangan usaha Rumah Sakit mempersyaratkan adanya daya saing bagi Rumah Sakit agar dapat memenangkan persaingan yang ada. Salah satu bentuk daya saing yang harus diciptakan oleh usaha Rumah Sakit adalah kualitas layanan. Rumah Sakit harus berupaya meningkatkan kualitas jasa pe- layanannya secara terus menerus. Semakin tinggi tingkat pemahaman masyarakat terhadap pentingnya kesehatan untuk mempertahankan kualitas hidup, maka masyarakat pengguna akan semakin kritis dalam menerima produk jasa. Oleh karena itu, peningkatan kualitas layanan Rumah Sakit perlu terus menerus dilakukan.

Berbagai indikator yang sering dipergunakan untuk mengukur kualitas layanan adalah intangibility, perishability, costumer contact, variability, physical distribution chain (Kotler \& Amstrong, 1996). Pendapat yang sama dikemukakan oleh Zethmal, Berry \& Parasuraman dalam Kotler (2002) bahwa ada lima dimensi kualitas jasa, yaitu: tangibles reliability, responsiveness, assurance, dan empathy.

Menurut Parasuraman dalam Tjiptono (1999), penilaian pasien terhadap kualitas ditentukan oleh dua hal, yaitu harapan pasien terhadap kualitas (expected quality) dan persepsi pasien atas kualitas (perceived quality). Berdasarkan pertimbangan tersebut, maka pengukuran keberhasilan suatu perusahaan jasa Rumah Sakit, lebih banyak ditentukan oleh penilaian dan persepsi pasien tentang kualitas pelayanan yang diberikan.

Persepsi pasien tentang pelayanan memegang peranan yang sangat penting. Kualitas pelayanan akan terpenuhi apabila proses penyampaian jasa dari pemberi jasa kepada pasien sesuai dengan apa yang dipersepsikan oleh pasien. Lebih lanjut Welch dalam Kotler (2002) menyatakan bahwa kualitas layanan merupakan jaminan terbaik untuk menciptakan dan mempertahankan kesetiaan konsumen dan benteng pertahanan dalam menghadapi persaingan global. 
Baloglu (2002) menyatakan bahwa loyalitas pelanggan memiliki lima diemsi, yaitu kepercayaan (trust), komitmen psikologi (psychological comitment), perubahan biaya (switching cost), perilaku publisitas (word-of-mouth), dan kerjasama (cooperation).

Caruana (2002) dalam hasil penelitiannya menemukan bahwa kualitas layanan berpengaruh terhadap loyalitas konsumen. Lebih lanjut, Rifai (2005) menyimpulkan dalam penelitiannya bahwa persepsi masyarakat tentang kualitas jasa pelayanan kesehatan dan pengaruhnya terhadap pemanfaatan jasa pelayanan kesehatan merupakan indikator utama keberhasilan jasa pelayanan kesehatan.

Parasuraman, et al. (1994) menyatakan bahwa kualitas layanan merupakan konsep yang terdiri dari lima dimensi, yaitu tangible, reliability, responsiveness, assurance dan empaty. Lima dimensi ini sangat berperan dalam membentuk tingkat loyalitas pelanggan.

Dimensi tampilan fisik (tangible) yang diberikan perusahaan kepada pelanggan seperti fasilitas fisik, perlengkapan, keramahan pegawai akan mempengaruhi tingkat loyalitas pelanggan. Semakin konsumen merasakan nilai tangible yang diberikan perusahaan semakin meningkatkan loyalitas pelanggan tersebut. Hasil penelitian Loveloc \& Wright (2005) menyimpulkan bahwa tampilan fisik (tangible) memberi petunjuk tentang kualitas jasa dan akan mempengaruhi pelanggan dalam menilai jasa tersebut, sehingga perlu dipikirkan sifat dari bukti fisik bagi pelanggan.

Dimensi kehandalan (reliability) dari pelayanan yang diberikan oleh perusahaan dalam bentuk kecepatan, keakuratan dan memuaskan akan berdampak pata tingginya tingkat loyalitas mereka terhadap produk perusahaan tersebut. Hal senada dikemukakan Lovelock \& Wright (2005) yang menyatakan perlu ada kesesuaian antara pelayanan yang diberikan dengan apa yang dibutuhkan dari waktu ke waktu.

Dimensi daya tanggap (responsiveness) para karyawan perusahaan dalam melayani pelanggan. Ketika pelayanan yang baik yang diberikan oleh para karyawan akan terbentuk hubungan kekeluargaan. Hal ini akan berdampak pada tingkat loyalitas pelanggan terhadap perusahaan. Hasil penelitian Sabihaini (2002) menyimpulkan bahwa dimensi responsiveness berpengaruh terhadap tingkat loyalitas pasien.

Dimensi jaminan (assurance) mencakup pengetahuan, kemampuan, kesopanan dan sifat dapat dipercaya karyawan terhadap konsumen. Nilai yang terhantar akan membentuk loyalitas pelanggan.
Hasil penelitian Cronin et al. (2000) yang menyimpulkan dimensi assurance mempunyai hubungan dan pengaruh terhadap loyalitas.

Dimensi empati (empathy) mencakup hubungan komunikasi, perhatian dan pemahaman kebutuhan konsumen. Jika konsumen merasa bahwa para karyawan perusahaan dapat memberikan empati kepada konsumen maka mereka tidak lagi merasa ragu untuk tetap mengkonsumsi jasa yang diberikan. Hal ini akan membentuk tingkat Loyalitas pelanggan. Hasil penelitian Haryono et al. (2006) menyimpulkan terdapat hubungan yang searah antara dimensi empati terhadap loyalitas pasien.

Berdasarkan uraian di atas, maka penelitian ini melakukan kajian tentang pengaruh kualitas layanan terhadap loyalitas pasien Rumah Sakit Umum Swasta di Kota Singaraja-Bali. Pemilihan Rumah Sakit Umum Swasta sebagai obyek penelitian ini didasarkan atas pertimbangan bahwa pasien yang berkunjung memiliki status membayar sendiri biaya pelayanan Rumah Sakit dan tidak memiliki keterkaitan apa pun yang mengharuskan pasien berobat di Rumah Sakit Swasta tersebut. Pasien bebas memilih tempat berobat sesuai dengan pilihan pasien sendiri, berdasarkan kualitas yang dianggap sesuai dan memuaskan.

\section{KAJIAN TEORITIS}

Teori pertama yang mendukung penelitian ini adalah teori kualitas layanan oleh Parasuraman et al., (1994) yang menyatakan bahwa kualitas layanan memiliki lima dimensi, yaitu tampilan fisik (tangibles), empati (emphaty), kehandalan (reliability), daya tanggap (responsiveness), jaminan (assurance), dan empati (emphaty).

Teori kedua yang mendukung penelitian ini adalah teori loyalitas pelanggan oleh Baloglu, (2002) yang menyatakan bahwa loyalitas pelanggan memiliki lima dimensi, yaitu kepercayaan (trust), komitmen psikologi (psychological comitment), perubahan biaya (switching cost), perilaku publisitas (word-ofmouth), dan kerjasama (cooperation).

Berdasarkan kajian kepustakaan sebelumnya, kerangka konseptual dalam penelitian ini dapat dilihat dalam Gambar 1.

\section{Hipotesis Penelitian}

Hipotesis dibangun atas teori dan hasil penelitian sebelumnya sebagai berikut:

Hipotesis 1: Kualitas layanan yang terdiri dari tampilan fisik (tangibles), empati (emphaty), kehandalan 
(reliability), daya tanggap (responsiveness), jaminan (assurance), dan empati (emphaty) berpengaruh secara simultan terhadap loyalitas pasien.

Hipotesis 2: Kualitas layanan yang terdiri dari tampilan fisik (tangibles), empati (emphaty), kehandalan (reliability), daya tanggap (responsiveness), jaminan (assurance), dan empati (emphaty) berpengaruh secara parsial terhadap loyalitas pasien.

Hipotesis 3: Jaminan (assurance) mempunyai pengaruh dominan terhadap loyalitas pasien.

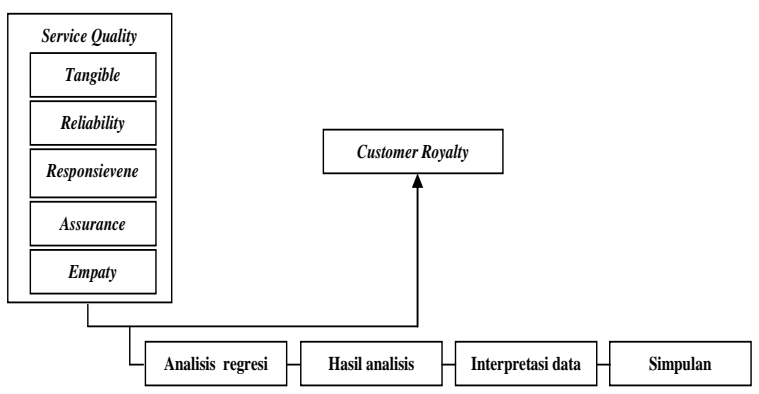

Gambar 1. Model Kerangka Konseptual

\section{Kerangka Hipotesis}

Berdasarkan kerangka konsep penelitian diatas, maka kerangka hipotesis dalam penelitian ini dapat dilihat dalam Gambar 2.
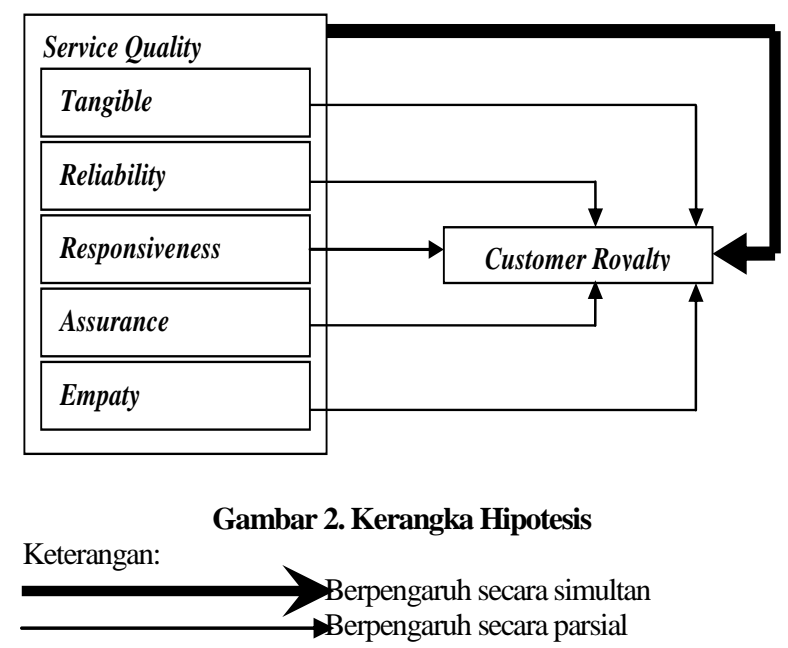

\section{METODE PENELITIAN}

\section{Lokasi Penelitian}

Penelitian ini dilaksanakan di kota SingarajaBali dengan menetapkan 4 (empat) buah Rumah Sakit Umum Swasta, yaitu (1) Rumah Sakit Umum Kerta Usada, (2) Rumah Sakit Umum Karya Darma Usada, (3) Rumah Sakit Umum Parama Sidi, dan (4) Rumah Sakit Umum TNI.

\section{Objek Penelitian}

Penelitian ini menetapkan pasien Rumah Sakit Umum Swasta yang bersumber dari rumah tangga yang telah menggunakan jasa Rumah Sakit Umum Swasta di kota Singaraja-Bali. Pasien yang telah menggunakan jasa Rumah Sakit Umum Swasta dimintai persepsinya terhadap dua variabel penelitian, yaitu kualitas layanan dan loyalitas pasien. Kualitas layanan Rumah Sakit menyangkut tampilan fisik (tangibles), empati (emphaty), kehandalan (reliability), daya tanggap (responsiveness), jaminan (assurance), dan empati (emphaty).

Sedangkan loyalitas pasien terdiri atas: kepercayaan (trust), komitmen psikologi (psychological comitment), perubahan biaya (switching cost), perilaku publisitas (word-of-mouth), dan kerjasama (cooperation).

\section{Populasi dan Sampel.}

Populasi penelitian ini adalah keseluruhan pasien yang berkunjung selama satu bulan yang berjumlah 57.695 orang.

Oleh karena jumlah populasi terlalu banyak, maka ditetapkan jumlah sampel yang representatif, untuk mewakili populasi yang ada. Besarnya jumlah sampel menggunakan rumus Slovin (dalam Sugiyono, 2005) yaitu:

$\mathrm{n}=\frac{\mathrm{N}}{1+\mathrm{Ne}}$

Dalam penelitian ini, jumlah populasi $(\mathrm{N})$ sebesar 57.695 orang, sedangkan e ditetapkan $1 \%$. Berdasarkan rumus diatas, akan diperoleh sampel minimal 99,82 atau dibulatkan menjadi 100 orang.

Pengambilan sampel dilakukan dengan metode purposive sampling, yaitu jumlah pasien yang dijadikan sampel di masing-masing Rumah Sakit diambil secara proporsional, yaitu 20 orang dari setiap Rumah Sakit.

\section{Identifikasi Variabel}

Penelitian ini terdiri dari variabel bebas (independent variable) dan variabel terikat (dependent variable). Variabel bebas (independent variable) yang sifatnya tidak dipengaruhi variabel lain, tetapi mempengaruhi variabel lain adalah kualitas layanan, yang terdiri atas tampilan fisik, kehandalan, ketanggapan, jaminan, dan empati. Sedangkan variabel terikat (dependent variable) adalah loyalitas pasien. Adapun identifikasi kedua variabel tersebut disajikan pada Tabel 2. 
Tabel 2. Variabel, Dimensi, Indikator dan Skala Pengukuran Kualitas Layanan

\begin{tabular}{|c|c|c|c|}
\hline & Dimensi & Indikator & Pengukuran \\
\hline \multirow{5}{*}{\multicolumn{2}{|c|}{$\begin{array}{l}\text { Kualitas layanan } 1 \\
(\mathrm{KL})\end{array}$}} & $\begin{array}{ll}\text { 1. } & \text { Kemoderenan perlengkapan } \\
2 & \text { Kerapian tenaga medis }\end{array}$ & Skala likert 5 \\
\hline & & 2. Kerapian tenaga medis & \\
\hline & & $\begin{array}{l}\text { 3. Kebersihan, keindahan dan kerapian ruang rawat } \\
\text { 4. Kelengkapan fasilitas }\end{array}$ & \\
\hline & & 5. Kenyamanan selama perawatan & \\
\hline & & 6. Kenyamanan tempat tidur di ruang rawat & \\
\hline \multirow{5}{*}{\multicolumn{2}{|c|}{$\begin{array}{l}\text { 2. Kehandalan (reliable), } \\
\left(\mathrm{X}_{1.2}\right)\end{array}$}} & 7. Ketepatan waktu layanan. & Skala likert 5 \\
\hline & & 8. Ketepatan waktu pendaftaran di loket & point \\
\hline & & 9. Ketepatan waktu mulai pengobatan & \\
\hline & & 10. Ketepatan waktu selesai pengobatan & \\
\hline & & 11. Lama pengobatan & \\
\hline \multirow{8}{*}{\multicolumn{2}{|c|}{$\begin{array}{l}\text { 3. Ketanggapan (responsiveness), } \\
\left(\mathrm{X}_{1.3}\right)\end{array}$}} & 12 Ketanggapan tenaga medis terhadap permasalahan pasien & Skala likert 5 \\
\hline & & 13. Keramahan tenaga medis selama perawatan & \\
\hline & & $\begin{array}{l}\text { 14. Kecepatan tenaga medis memberikan pelayanan saat } \\
\text { dibutuhkan selama perawatan }\end{array}$ & \\
\hline & & 15. Fasilitas yang diperoleh selama perawatan & \\
\hline & & 16. Pelayanan makan dan minum selama perawatan & \\
\hline & & 17. Dapat memberikan pelayanan dengan cepat & \\
\hline & & 18. Kesediaan tenaga medis menerima sumbang saran dari & \\
\hline & & pasien. & \\
\hline \multirow{6}{*}{\multicolumn{2}{|c|}{ 4. Jaminan (assurance), $\left(\mathrm{X}_{1.4}\right)$}} & $\begin{array}{l}\text { 19. Kemampuan dan pengetahuan tenaga medis selama } \\
\text { perawatan }\end{array}$ & $\begin{array}{l}\text { Skala likert } 5 \\
\text { point }\end{array}$ \\
\hline & & 20. Keamanan selama perawatan & \\
\hline & & 21. Resiko keselamatan selama perawatan & \\
\hline & & 22. Keamanan barang bawaan & \\
\hline & & 23. Perilaku tenaga medis selama perawatan & \\
\hline & & 24. Pengalaman tenaga medis dalam melayani pasien. & \\
\hline \multirow{6}{*}{\multicolumn{2}{|c|}{ 5. Empati (Empaty), $\left(\mathrm{X}_{1.5}\right)$}} & 25. Kemudahan dalam pemesanan tempat berobat. & Skala likert 5 \\
\hline & & 26 Kemudahan dalam pembayaran ongkos rawat & point \\
\hline & & 27. Kemudahan dalam mencapai lokasi perawatan & \\
\hline & & 28. Kemudahan dalam mengurus administrasi perawatan & \\
\hline & & 29. Pengertian dan pemahaman tenaga medis selama & \\
\hline & & $\begin{array}{l}\text { perawatan } \\
\text { 30. Perhatian personal tenaga medis selama perawatan }\end{array}$ & \\
\hline
\end{tabular}

Sumber: Kajian Teori

Tabel 3. Variabel, Dimensi, Indikator dan Skala Pengukuran Loyalitas Pasien

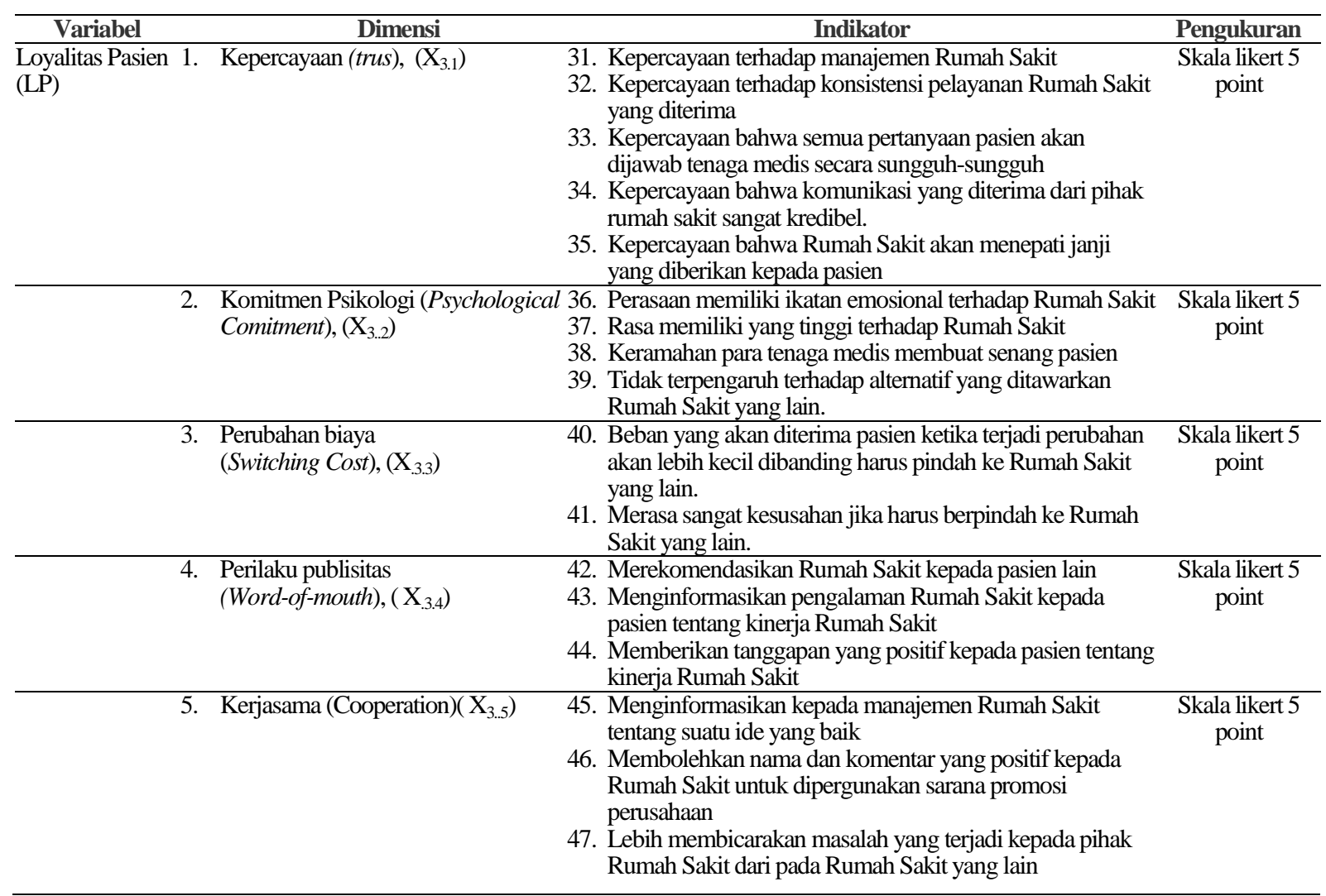




\section{Teknik Pengumpulan Data}

Data dikumpulkan dengan tiga cara, yaitu (1) kuesioner yang bersifat tertutup, yakni pertanyaan yang disusun sedemikian rupa sehingga responden dibatasi dalam memberi jawaban atas beberapa alternatif atau satu jawaban saja. Kuesioner yang telah dibuat kemudian dikirimkan kepada pasien Rumah Sakit Umum Swasta yang ada di kota SingarajaBali. Teknik pengukuran menggunakan summated agreement yang dikembangkan oleh Likert. Pengukuran ini membedakan 5 (lima) alternatif jawaban dimulai dari Sangat Setuju (SS), Setuju (S), Raguragu (RR), Tidak Setuju (TS), dan Sangat Tidak Setuju (STS). Masing-masing jawaban diberi nilai 5 sampai 1. (2) Wawancara, yaitu melakukan tanya jawab langsung antara peneliti dengan pihak-pihak yang terkait guna mendapatkan informasi tambahan atau pendukung. (3) Dokumentasi, yaitu suatu metode pengumpulan data dengan mempelajari dokumen yang ada pada Rumah Sakit Umum Swasta di kota Singaraja-Bali.

\section{Definisi Operasional Variabel}

Kualitas layanan dalam penelitian ini adalah tanggapan pasien setelah merasakan kualitas layanan yang diterimanya selama mengikuti perawatan di Rumah Sakit, yang terdiri dari tampilan fisik (tangible), empati (empaty), kehandalan (reliable), ketanggapan (responsiveness), dan jaminan (assurance).

Tampilan fisik (tangible) adalah penilaian pasien (responden) terhadap kemampuan Rumah Sakit Umum Swasta di kota Singaraja yang berkaitan dengan perlengkapan yang dimiliki, tenaga medis yang ada, ruang perawatan yang nyaman, fasilitas yang memadai, dan kenyamanan selama perawatan.

Kehandalan (reliability) adalah penilaian pasien (responden) terhadap kemampuan Rumah Sakit Umum Swasta di kota Singaraja yang berkaitan dengan ketepatan waktu pelayanan, waktu untuk mengurus pendaftaran, waktu memulai pengobatan, waktu mengakhiri pengobatan, kesesuaian antara harapan dan realisasi waktu bagi pasien.

Ketanggapan (responsivenes) adalah penilaian pasien (responden) terhadap kemampuan Rumah Sakit Umum Swasta di kota Singaraja yang berkaitan dengan ketanggapan petugas atas keluhan dan masalah yang dihadapi, keramah tamahan petugas, kecepatan petugas, kelengkapan fasilitas, makanan dan minuman yang berkualitas.

Jaminan (assurance) adalah penilaian pasien (responden) terhadap kemampuan Rumah Sakit Umum Swasta di kota Singaraja yang berkaitan dengan kemampuan dan pengetahuan, jaminan keamanan, jaminan keselamatan, perilaku petugas yang baik, pengalaman yang memadai.

Empati (emphaty) adalah penilaian pasien (responden) terhadap kemampuan Rumah Sakit Umum Swasta di kota Singaraja yang berkaitan dengan kemudahan dalam pemesanan, kemudahan dalam pembayaran ongkos, kemudahan dalam mencapai lokasi, kemudahan dalam mengurus administrasirasa, pengertian dan pemahaman petugas, perhatian yang tinggi dari petugas.

Loyalitas pasien adalah tanggapan tentang komitmen pasien Rumah Sakit Umum Swasta untuk setia berobat serta tetap melakukan permintaan jasa perawatan secara konsisten, yang terdiri dari kepercayaan (trust), komitmen psikologi (psychological commitment), perubahan biaya (switching cost), perilaku publisitas (word-of-mouth), dan kerjasama yang baik (cooperation).

\section{Teknik Analisis Data}

Untuk menganalisis pengaruh tampilan fisik (tangibles), kehandalan (reliability), daya tanggap (responsiveness), jaminan (assurance), dan empati (emphaty) terhadap loyalitas pasien, digunakan model regresi linear berganda, sebagaimana dimodelkan sebagai berikut:

$\mathrm{Y}=\beta_{0}+\beta_{1} \mathrm{x}_{\mathrm{i}}+\beta_{2} \mathrm{x}_{2}+\beta_{3} \mathrm{x}_{3}+\beta_{4} \mathrm{x}_{4}+\beta_{5} \mathrm{x}_{5}+\mathrm{u}$

Keterangan:

$\mathrm{Y}=$ Loyalitas pasien

$\mathrm{X}_{1}=$ Tampilan Fisik (tangible)

$\mathrm{X}_{2}=$ Keandalan (Reliability)

$\mathrm{X}_{3}=$ Ketanggapan (Responsivenes)

$\mathrm{X}_{4}=$ Jaminan (Assurance)

$\mathrm{X}_{5}=$ Empati (Emphaty)

$\mathrm{E}=$ Variabel pengganggu

$\beta_{0}=$ Konstanta

$\beta_{1,} \beta_{2}, \beta_{3}, \beta_{4}, \beta_{5}=$ koefisien tiap-tiap variabel

\section{HASIL DAN PEMBAHASAN}

\section{Hasil Penelitian}

Hasil analisis regresi berganda pengaruh tampilan fisik (tangibles), kehandalan (reliability), daya tanggap (responsiveness), jaminan (assurance), dan empati (emphaty) terhadap loyalitas pasien, disajikan dalam Tabel 4. Dengan demikian, persamaan regresi berganda loyalitas pasien dinyatakan sebagai berikut:

$Y=-1,356+0,156 X_{1}+0,244 X_{2}+0,652 X_{3}+0,023 X_{4}$ $+0,283 \mathrm{X}_{5}$ 
Tabel 4. Hasil Analisis Regresi Berganda

\begin{tabular}{|c|c|c|c|c|c|c|}
\hline \multirow{3}{*}{ Model } & & \multicolumn{2}{|c|}{$\begin{array}{c}\text { Unstandardized } \\
\text { Coefficients } \\
\end{array}$} & \multirow[t]{2}{*}{$\begin{array}{l}\text { Standardized } \\
\text { Coefficients } \\
\end{array}$} & \multirow{3}{*}{$\mathrm{t}$} & \multirow{3}{*}{ Sig. } \\
\hline & & & Std. & & & \\
\hline & & B & Error & Beta & & \\
\hline \multirow[t]{6}{*}{1} & (Constant) & -1.356 & .459 & & -2.957 & .004 \\
\hline & K11 & .156 & .072 & .097 & 2.156 & .034 \\
\hline & $\mathrm{K} 12$ & .244 & .049 & 260 & 4.929 & .000 \\
\hline & $\mathrm{K} 13$ & .652 & .067 & .638 & 9.757 & .000 \\
\hline & K14 & .023 & .050 & .021 & .450 & .653 \\
\hline & $\mathrm{K} 15$ & .283 & .107 & .155 & 2.639 & .010 \\
\hline
\end{tabular}

Berdasarkan hasil penelitian, diperoleh nilai $\mathrm{F}$ sebesar 330,251. Dengan menggunakan tingkat keyakinan $95 \%(\alpha=5 \%)$ dan derajat kebebasan $5 / 100$, diperoleh hasil $\mathrm{F}$ table sebesar 2,29. Hal ini berimplikasi pada penolakan terhadap Ho. Dalam kalmat lain, secara simultan ada pengaruh yang signifikan antara tampilan fisik (tangibles), kehandalan (reliability), daya tanggap (responsiveness), jaminan (assurance), dan empati (emphaty) terhadap loyalitas pasien.

Hasil $t$-test untuk proksi kualitas layanan memberikan kesimpulan jika dimensi tampilan fisik (tangibles), kehandalan (reliability), daya tanggap (responsiveness) dan empati (emphaty) memberikan pengaruh signifikan terhadap loyalitas pasien (Tabel 5).

Tabel 5. Hasil Uji Parsial Kualitas Layanan

\begin{tabular}{clccc}
\hline No & \multicolumn{1}{c}{ Dimensi } & $\mathbf{t}_{\text {hitung }}$ & $\begin{array}{c}\mathbf{T} \text { tabel } \\
(\boldsymbol{\alpha = 5 \% )})\end{array}$ & Keterangan \\
\hline 1 & $\begin{array}{l}\text { Tampilan fisik } \\
\text { (Tangibles) }\end{array}$ & 2,156 & 1,98 & Signifikan \\
2 & $\begin{array}{l}\text { Kehandalan } \\
\text { (Reliability }\end{array}$ & 4,929 & 1,98 & Signifikan \\
3 & $\begin{array}{l}\text { Daya tanggap } \\
\text { (Responsiveness); }\end{array}$ & 9,757 & 1,98 & Signifikan \\
4 & Jaminan(Assurance) & 0,450 & 1,98 & $\begin{array}{c}\text { Tidak } \\
5\end{array}$ \\
& Empati(Emphaty) & 2,639 & 1,98 & $\begin{array}{l}\text { Signifikan } \\
\text { Signifikan }\end{array}$ \\
\hline
\end{tabular}

\section{Uji Determinasi}

Uji ini ditujukan untuk mengetahui dimensi yang paling berpengaruh terhadap Loyalitas pasien.

Tabel 6. Nilai Determinasi

\begin{tabular}{lcc}
\hline \multicolumn{1}{c}{ Variabel bebas } & $\begin{array}{c}\text { Koefisien } \\
\text { Korelasi }\end{array}$ & Determinasi \\
\hline Tampilan fisik(Tangibles) & 0,145 & 2,1 \\
Kehandalan (Reliability) & 0,202 & 4,0 \\
Daya tanggap (Responsiveness) & 0,197 & 3,8 \\
Jaminan (Assurance) & 0,092 & 0,8 \\
Empati (Emphaty) & 0,077 & 0,5 \\
\hline
\end{tabular}

Berdasarkan Tabel 6 di atas nilai determinasi tertinggi adalah dimensi kehandalan (reliability), maka dimensi yang paling dominan mempengaruhi loyalitas pasien adalah dimensi kehandalan (reliability).

\section{Pembahasan Hasil Penelitian}

\section{Pengaruh Dimensi Kualitas Layanan Secara Simultan Terhadap Loyalitas Pasien}

Hasil penelitian menunjukkan bahwa secara simultan terdapat pengaruh positif dan signifikan antara dimensi kualitas layanan terhadap loyalitas pasien. Artinya baik tidaknya kualitas layanan akan menyebabkan tinggi rendahnya loyalitas pasien Rumah Sakit Umum Swasta. Dimensi tampilan fisik (tangibles), kehandalan (reliability), daya tanggap (responsiveness), jaminan (assurance), dan empati (emphaty) secara bersama-sama akan menyebabkan tinggi rendahnya loyalitas pasien.

Hasil penelitian ini mendukung teori yang dikemukakan oleh Parasuraman et al. (1994), serta Caurana (2002) dan Rifai (2005) yang menemukan bahwa kualitas layanan mempunyai pengaruh terhadap loyalitas konsumen.

\section{Pengaruh Dimensi Kualitas Layanan Secara Parsial Terhadap Loyalitas Pasien}

- Pengaruh Dimensi Tampilan Fisik (Tangible) terhadap Tingkat Loyalitas Pasien

Tangible adalah wujud kenyataan secara fisik yang meliputi perlengkapan yang dimiliki, tenaga medis yang ada, ruang perawatan yang nyaman, fasilitas yang memadai dan kenyamanan selama perawatan. Berdasarkan hasil analisis multivariat pada penelitian Rumah Sakit Swasta di kota SingarajaBali memperlihatkan bahwa tampilan fisik (tangible) mempunyai pengaruh positif dan signifikan terhadap tingkat loyalitas pasien Rumah Sakit Umum Swasta di kota Singaraja-Bali, dengan nilai signifikan $(\mathrm{p}=0$, 000 ) dan nilai koefisien regresi $=0,156$.

Hasil penelitian ini mendukung teori yang dikemukakan Parasuraman et al. (1994), penelitian Lovelock \& Wright (2005), karena kinerja jasa tidak berwujud, bukti fisik memberi petunjuk tentang kualitas jasa dan dalam beberapa hal akan sangat mempengaruhi pelanggan dalam menilai jasa tersebut, sehingga perlu dipikirkan secara cermat sifat dari bukti fisik bagi pelanggan. Pernyataan tersebut sesuai dengan hasil penelitian yang dilakukan. Penampilan Rumah Sakit Umum Swasta yang baik akan membuat pasien loyal. 
- Pengaruh Dimensi Kehandalan (Reliability) terhadap Tingkat Loyalitas Pasien.

Kehandalan (reliability) adalah penilaian pasien (responden) terhadap kemampuan Rumah Sakit Umum di kota Singaraja yang berkaitan dengan ketepatan waktu pelayanan, waktu untuk mengurus pendaftaran, waktu memulai pengobatan, waktu mengakhiri pengobatan, kesesuaian antara harapan dan realisasi waktu bagi pasien. Berdasarkan hasil analisis multivariat pada penelitian Rumah Sakit Umum Swasta di kota Singaraja - Bali, $r=0,244, p=$ $0,000<0,05$. Hal ini menunjukkan bahwa kehandalan (reliability) mempunyai pengaruh positif dan signifikan terhadap tingkat loyalitas pasien.

Hasil penelitian ini mendukung pendapat Parasuraman et al. (1994), Lovelock \& Wright (2005), yang menyatakan bahwa perlu ada kessuaian antara pelayanan medis yang diberikan dengan apa yang dibutuhkan dari waktu ke waktu. Oleh karenanya, pihak Rumah Sakit dapat memperbaiki pelayanannya, waktu pendaftaran pasien, waktu pengobatan, waktu mengakhiri pengobatan, sehingga apa yang menjadi harapan pasien akan dipenuhi. Hal ini dapat dimaklumi karena karakteristik orang berobat berbeda dengan orang sehat. Orang sakit memerlukan layanan yang serba cepat dalam segala segi bentuk pelayanan. Jika lambat akan dapat menyebabkan nyawa orang melayang. Dengan demikian, dapat dikatakan bahwa efektivitas waktu pelayanan akan menentukan loyalitas pasien dalam jangka panjang.

- Pengaruh Dimensi Daya Tanggap (Responsiveness) terhadap Loyalitas Pasien

Melalui ketanggapan (responsivenes) ingin mendapatkan respon pasien sejauhmana pihak Rumah sakit Umum Swasta di Kota Singaraja memberikan respon yang berkaitan dengan ketanggapan petugas atas keluhan dan masalah yang dihadapi, keramah tamahan petugas, kecepatan petugas, kelengkapan fasilitas, makanan dan minuman yang berkualitas.

Berdasarkan hasil analisis multivariat, didapatkan nilai $r=0,595, p=0,001<0,05$ hal ini berarti menunjukkan bahwa Ketanggapan (responsiveness) mempunyai pengaruh positif dan signifikan terhadap tingkat loyalitas pasien Rumah sakit Umum di kota Singaraja-Bali.

Hasil penelitian mendukung pendapat Parasuraman et al. (1994) serta hasil penelitian Sabihaini (2002) yang menyimpulkan bahwa dimensi responsiveness berpengaruh terhadap tingkat loyalitas pasien.
Cara petugas merespon keluhan dan masalah yang dihadapi pasien, keramah-tamahan, kecepatan, ketersediaan peralatan setiap dibutuhkan, kualitas makanan dan minuman dari sudut kesehatan, kebersihan dan cita rasa akan sangat menentukan loyalitas pasien.

- Pengaruh Dimensi Jaminan (Assurance) terhadap Loyalitas Pasien

Melalui jaminan (assurance) ingin diketahui sejauhmana pihak Rumah Sakit Umum Swasta di kota Singaraja-Bali mampu memberikan jaminan kepada pasien dalam bentuk kemampuan dan pengetahuan, jaminan keamanan, jaminan keselamatan, perilaku petugas yang baik, pengalaman yang memadai.

Berdasarkan hasil analisis multivariat, didapatkan nilai $r=0,023, p=0,653>0,05$ hal ini berarti menunjukkan bahwa dimensi jaminan (assurance) tidak berpengaruh terhadap tingkat loyalitas pasien.

Hasil penelitian ini bertolak belakang dengan pendapat Parasuraman et al. (1994), serta hasil penelitian Cronin et al. (2000) yang menyimpulkan bahwa variabel assurance yang termasuk kedalam dimensi service quality mempunyai hubungan dan pengaruh yang signifikan dengan variabel loyalitas. Hal ini menunjukkan bahwa Rumah Sakit Umum di kota Singaraja belum mampu memberikan jaminan yang memuaskan, sehingga responden memberikan persepsi kurang terhadap alat ukur yang ditetapkan peneliti. Deskripsi tanggapan responden terhadap dimensi jaminan (assurance) menunjukkan nilai ratarata 3,60 dari interval 1-5. Hasil wawancara dengan responden yang menjawab kurang terhadap dimensi jaminan (assurance) menyatakan bahwa jaminan keamanan masih kurang.

- Pengaruh Dimensi Empati (Emphaty) terhadap Loyalitas Pasien

Melalui dimensi empati (emphaty) ingin diketahui sejauhmana pihak Rumah Sakit Umum Swasta di kota Singaraja - Bali memiliki kemampuan dalam memberikan perhatian penuh kepada pasien yang berkaitan dengan kemudahan dalam pemesanan, kemudahan dalam pembayaran ongkos, kemudahan dalam mencapai lokasi, kemudahan dalam mengurus administrasi, rasa pengertian, pemahaman petugas, dan perhatian yang tinggi dari petugas.

Berdasarkan hasil analisis multivariat, didapatkan nilai $r=0,283, p=0,010<0,05$. Hal ini berarti menunjukkan bahwa dimensi empati (emphaty) mempunyai pengaruh positif dan signifikan terhadap 
tingkat loyalitas pasien Rumah Sakit Umum Swasta di kota Singaraja-Bali.

Hasil penelitian ini bersifat mendukung pendapat Parasuraman et al. (1994) serta hasil penelitian yang dilakukan oleh Haryono et al. (2006) yang menyimpulkan terdapat hubungan yang searah antara dimensi empati (emphaty) terhadap loyalitas pasien. Hal ini menunjukkan bahwa Rumah Sakit Umum Swasta di kota Singaraja-Bali telah mampu memberikan perhatian penuh kepada pasien, sehingga melahirkan loyalitas pasien.

- Dimensi yang Paling Dominan Berpengaruh Terhadap Loyalitas Pasien

Hasil analisis multivariat menunjukkan bahwa dimensi kehandalan (reliability) adalah dimensi yang paling dominan mempengaruhi loyalitas pasien Rumah Sakit Umum Swasta di kota Singaraja-Bali. Hal ini menunjukkan bahwa Rumah Sakit Umum di kota Singaraja-Bali memiliki keunggulan dalam menentukan alokasi waktu layanan, sehingga pasien tidak memerlukan waktu yang lama dalam pelayanan, mengurus pendaftaran, pengobatan, serta waktu yang diperlukan untuk pelayanan sesuai dengan harapan pasien.

\section{KESIMPULAN DAN SARAN}

Kualitas layanan yang terdiri dari tampilan fisik (tangibles), empati (emphaty), kehandalan (reliability), daya tanggap (responsiveness), jaminan (assurance), dan empati (emphaty) berpengaruh secara parsial terhadap loyalitas pasien. Sedangkan keenam dimensi ini serta dimensi jaminan, berpengaruh secara simultan terhadap loyalitas pasien. Kehandalan (reliability) merupakan dimensi yang mempunyai pengaruh dominan terhadap loyalitas pasien.

Berdasarkan hasil-hasil penelitian, maka Rumah Sakit Umum Swasta di kota Singaraja-Bali hendaknya memperhatikan kualitas layanannya. Hasil analisis secara parsial menunjukkan bahwa dimensi jaminan (assurance) tidak berpengaruh terhadap loyalitas pasien. Untuk itu, pihak Rumah Sakit Umum Swasta di kota Singaraja-Bali perlu memberikan jaminan untuk meyakinkan para pasien bahwa berobat di Rumah Sakit Umum Swasta di kota Singaraja-Bali didukung oleh tenaga medis yang memiliki kemampuan dan pengetahuan yang memadai, jaminan rasa aman, terjamin keselamatannya, petugas yang memiliki perilaku yang baik serta yang berpengalaman luas. Kehandalan (reliability) sebagai dimensi yang mempunyai pengaruh dominan terhadap loyalitas pasien dapat dijadikan keunggulan bersaing bagi pihak Rumah Sakit Umum Swasta di kota Singaraja-Bali. Dengan demikian, dimensi ini harus mampu dipertahankan dan ditingkatkan secara berkelanjutan.

\section{DAFTAR PUSTAKA}

Baloglu, Seyhmus. 2002. "Dimensions of Customer Loyalty", European Journal of Marketing, page 1372-1388.

Caruana, Albert. 2002. "Service Loyalty: The Effects of Service Quality and the Mediating Role of Customer Satisfaction", European Journal of Marketing, page 811-828.

Cronin, J., K., Michael G. Brady \& Thomas M. Hult.2000. "Assesing The Effects of Quality, Value, and Customer Satisfaction on Consumer Behavioral Intentions in Service Environment", Journal of Retailing, page 193-218.

Gujarati, D. 1999. Ekonometrika Dasar, Edisi Bahasa Indonesia, Jakarta: Penerbit Erlangga.

Haryono, Erwin, Hari Kusnanto \& M. Syafril Nusyirwa. 2006. Hubungan Persepsi terhadap Kualitas Pelayanan dengan Minat Pemanfaatan Pelayanan Rawat Inap Puskesmas dan Balai Pengobatan Swasta di Kabupaten Tapanuli Tengah, Working Paper Series No.4, Universitas Gadjah Mada.

Kotler, P. 2002. Manajemen Pemasaran, Edisi Bahasa Indonesia, Jakarta: PT Prenhalindo.

Kotler, P. \& Gary Amstrong. 1996. Principles of Marketing, Seventh Edition, New Jersey: Prentice-Hall.

Lovelock, Cristopher \& K. Lauren, Wright. 2005. Manajemen Pemasaran Jasa, Edisi Bahasa Indonesia, Jakarta: Penerbit Indeks.

Parasuraman, A., V.A. Zeithaml \& L.L. Berry. 1994. "SERVQUAL: Review, Critique Research Agenda", Journal of Marketing, page 111-124.

Rifai, Achmad. 2005. Pengaruh Persepsi Masyarakat Terhadap Pemanfaatan Pelayanan Pengobatan di Puskesmas Binjai Kota Tahun 2004, Tesis tidak dipublikasikan. Medan: Universitas Sumatera Utara.

Sugiyono. 2005. Metode Penelitian Bisnis, Bandung: CV Alfabeta.

Sabihaini. 2002. "Analisis Konsekuensi Keperilakuan Kualitas Layanan: Suatu Kajian Empirik", Usahawan, hal: 29-36.

Tjiptono, Fandy. 1999. Prinsip-prinsip Total Quality Service, Yogyakarta: Penerbit Andi. 